\title{
Incidence of Plant-Destructive Nematodes and Associated Damages on Yams Grown in Nasarawa State, North-Central Nigeria
}

\author{
Christopher Oche Eche ${ }^{1,2}$, Obiageli Evelyn Okafor ${ }^{3}$ \\ ${ }^{1}$ Department of Crop and Environmental Protection, Federal University of Agriculture, Makurdi, Nigeria \\ ${ }^{2}$ Environmental Standards, Center for Innovation in Procurement, Environmental and Social Standards, Makurdi, Nigeria \\ ${ }^{3}$ Raw Materials Research and Development Council, Abuja, Federal Capital Territory, Abuja, Nigeria
}

Email address:

ceche@uam.edu.ng (C. O. Eche)

To cite this article:

Christopher Oche Eche, Obiageli Evelyn Okafor. Incidence of Plant-Destructive Nematodes and Associated Damages on Yams Grown in Nasarawa State, North-Central Nigeria. Journal of Plant Sciences. Vol. 9, No. 3, 2021, pp. 107-112. doi: 10.11648/j.jps.20210903.15

Received: May 22, 2021; Accepted: June 11, 2021; Published: June 22, 2021

\begin{abstract}
Plant-parasitic nematodes (PPNs) are a major risk to yam (Dioscorea spp.) production in Nigeria. With the aim of establishing plant-parasitic nematode genera associated with yam tubers in Nasarawa State in order to engender sustainable management options and mitigation policies for their control, surveys were conducted in the main yam-producing local government areas (LGAs) of Nasarawa. A total of 54 yam farms were surveyed for PPNs and their associated damage on yam using multi-stage sampling technique. Three communities each, in Lafia, Keana, Kokona, Awe, Obi and Doma LGAs were assessed for the incidence of PPNs and their associated damages on yam. A total of 54 farmers' fields and 60 yam tubers were assessed in the study. The survey revealed that the eleven PPNs genera were recovered from the soil and tubers of infected yam included Pratylenchus, Hoplolaimus, Helicotylenchus, Criconema, Meloidogyne, Rotylenchus, Scutellonema, Xiphenema, Tylenchulus, Trichodorus and Rotylenchus. Meloidogyne (75.29\%, Scutellonema (57.20) and Pratylenchus (44.55\%), in order of descending ranking, had the highest incidences across the six LGAs. The destructive activities of these nematodes lead to in unattractive, verrucose or knobby appearances on infected yam tubers, thereby resulting in low to extremely low tuber quality of marketable yams in Nasarawa State.
\end{abstract}

Keywords: Survey, Plant-Parasitic Nematodes, Discorea Spp, Yam, Nasarawa, Nigeria

\section{Introduction}

Yam (Dioscorea spp.) is taxonomically classified under the family Dioscoreaceae, genus Dioscorea and order Dioscoreales. According to Martin [1] and Olorunsanya [2], yam has over 600 species of which about six of them are socioeconomically important, edible and are a major source of carbohydrate when consumed as a delicacy. The edible species are white (Dioscorea rotundata) water (Dioscorea alata), yellow (Dioscorea cayenensis), aerial (Dioscorea bulbifera), Japanese (Dioscorea japonica) and Chinese (Dioscorea esculanta) yams. Out of these, white yam and water yam are species widely grown in the coastal region of rainforest, wood savanna and southern guinea savanna agroecological zones of Nigeria [3]. Benue, Nasarawa, Kwara, Taraba, Kogi and Niger have been reported to be the major yam-producing states in Nigeria [4].

Yam is a rich source of carbohydrate and may be grilled, roasted, sautéed in oil, meshed, boiled, baked, minced into paste ("fufu") or made into pudding. It may be cooked or fried with rice, beans, plantain, sweet potato, lamb, chicken and butter nut as squash soup [5,6]. It can be boiled, roasted and eaten with oil, vegetable or sauce. The tubers may be peeled and sliced into tiny pieces and dried to very low moisture contents and milled into flour and flakes [7]. The tubers may be peeled and prepared into porridge and cooked with traditional spices and served for the sick and aged as appetizer. Despite the importance of yam, it is majorly plagued by activities of crop pests and diseases in field and storage environments [8]. Yam is prone to infection right 
from the seedling stage through to harvesting and even after harvesting, in storage [9]. Amongst the various constraints to production of yam, nematode pests are of significant importance [10-12].

Survey information of nematode-induced damages associated with yam cultivation in Nasarawa state are either not readily available or timeworn to engender further research and policy development that will ensure maximum returns along the yam value chain. It is also clear from recent findings that desert encroachment lines and climate change which has led to gradual shifts in agro-ecologies may have also impacted on disease spread in yamproducing communities [13]. It is against this backdrop that the survey was conducted to determine the presence, distribution, and extent of damage caused by plant-parasitic nematodes on selected yam fields in Nasarawa state, northcentral Nigeria.

\section{Materials and Methods}

\subsection{Study Area}

This study was conducted in Nasarawa state, north-central Nigeria. Nasarawa state is located between latitudes $7^{\circ}$ and $9^{\circ} \mathrm{N}$ and longitudes $7^{\circ}$ and $10^{\circ} \mathrm{E}$. Boundary states to Nasarawa are Benue (south), Kogi (west), the Federal Capital Territory (north-west), Kaduna and Plateau (north-east), and Taraba (south-east) as shown in Figure 1. Nasarawa state has a land area of 12,000 square kilometers and is divided into thirteen Local Government Areas (LGAs). The National Population Commission as at its last population count in 2006 pegged the state's population at $1,863,275$. Agriculture is the main livelihood of the people of Nasarawa state. Some of the main agrarian foodstuffs in the state include yam, cassava, maize, sorghum, millet, rice groundnut cowpea, soya beans, sesame, melon, sweet potato, mango, cashew, sugarcane, oil palm, cattle, sheep, goats, poultry, pigs and fisheries [14].

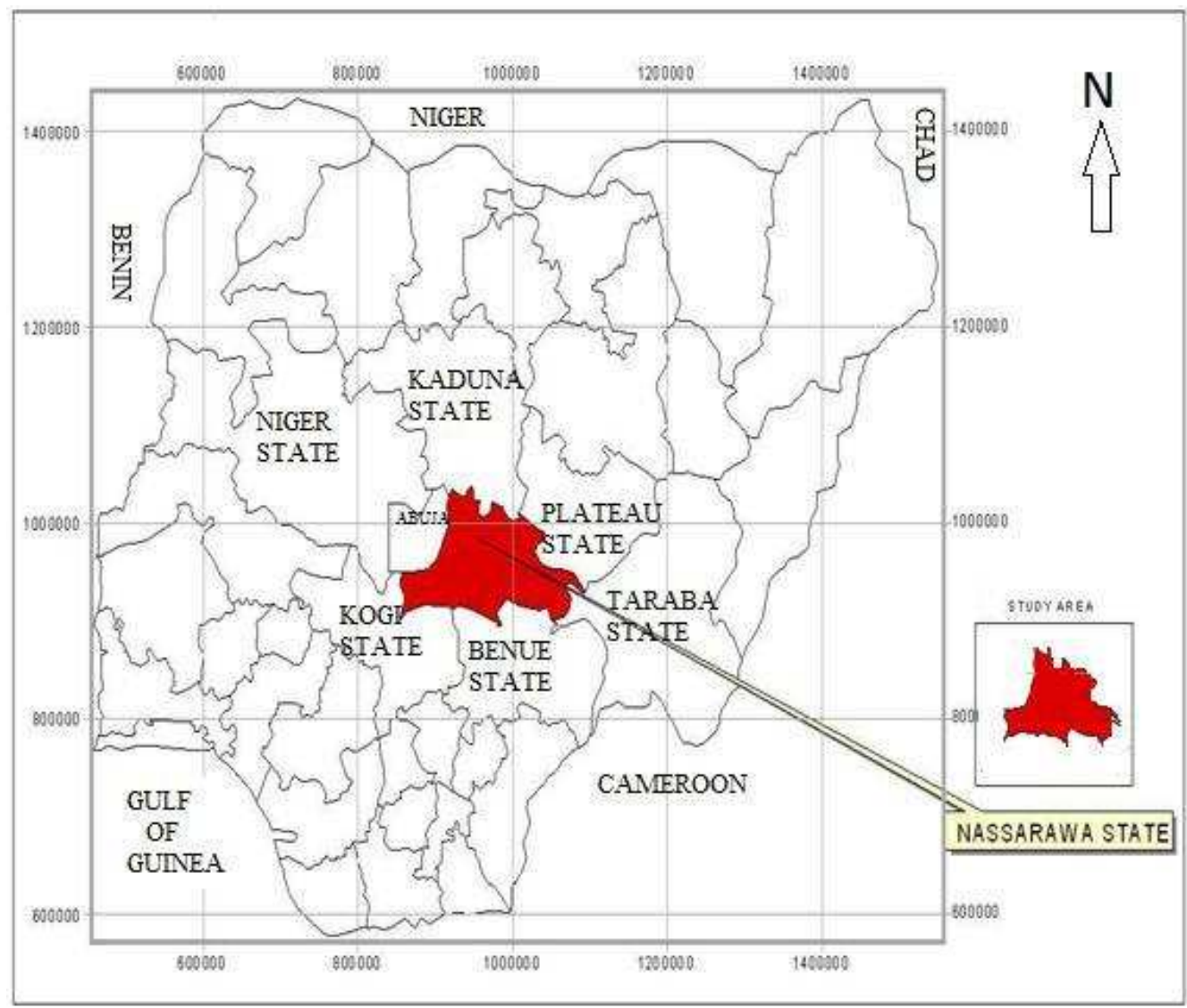

Figure 1. Map of Nasarawa State, Nigeria (Source: 15).

\subsection{Sample Collection}

A total of 54 yam farms were surveyed for plant-parasitic nematodes (PPNs) and their associated damage on yam. The survey was conducted between October to December, 2018 and January to February, 2019 in Nasarawa state using multistage sampling technique. Six local government areas (LGAs) in the state were selected based on available yam field data at the Nasarawa State Agricultural Development Programme. The LGAs included Lafia, Keana, Kokona, Awe,
Obi and Doma. From each LGA three communities were visited and three yam farms were assessed in each community for plant-parasitic nematode occurrence and damage on yam. In each farm, 10 plants were randomly selected from which four core samples from the rhizosphere of each plant were collected using a soil auger along the four cardinal directions at the base of each plant in order to cover as much of the rhizosphere as possible. Three tubers were collected from each surveyed farm. The four soil samples 
weighing $150 \mathrm{~g}$ each were collected to a depth of $30 \mathrm{~cm}$ with garden trowels and bulked into a composite sample of $200 \mathrm{~g}$. Samples from each farm were pooled and sealed in welllabelled plastic bags and protected from the sun [16]. Areas featuring high weed concentrations, areas next to terraces, and those containing limestone deposits, organic matter, and water features were avoided for sample collection.

\subsection{Nematode Extraction and Identification}

Extraction of nematodes from soil samples was done using the modification of Whitehead and Hemming tray method [17]. Two plastic sieves of same diameter $(15 \mathrm{~cm})$ with a double-ply tissue paper sandwiched in between the two sieves. The set of sandwiched sieves was later placed in an almost flat plastic bowl $20 \mathrm{~cm}$ in diameter having a slight depression at its center circumference. Fifty-four (54) of these set-ups were prepared and labelled appropriately using sliced pieces of masking tape which were attached to the edge of the top sieve and base of the bowl. Composite soil samples (200 g/sample) obtained from yam farms were carefully, and separately poured into each designated labelled set-up. At the base of the set-up, i.e., through the outer side of the basal sieve, $200 \mathrm{ml}$ of distilled water was gently poured to the tip of the depressed circumference of the bowl. The set-up was left standing for 48 hours.

Nematodes were also isolated from the tubers collected during the survey. Tuber cores (1 $\mathrm{cm}$ wide and $2 \mathrm{~cm}$ deep) consisting of yam skin, its sub-cutaneous layer and associated roots were peeled-off from each tuber using a sterilized knife recurrently, for each tuber sample. Cores from each farm were bulked to obtain composite core of 50 g. The cores were rinsed briefly in distilled water to remove soil, before they were finely chopped with a sterilized knife and placed on a modified Baermann's sieve [18] for 72 hours. Nematode extracts were collected daily and poured in appropriately labelled McCartney bottles kept in a refrigerator that was maintained at $25^{\circ} \mathrm{C}$ and replaced with fresh water on each occasion. Nematode suspensions for each sample were combined, reduced to $25 \mathrm{ml}$ and nematode population densities assessed from $3 \times 2$ ml- aliquots using a light microscope. Roots were first rinsed in tap-water to remove soil debris, dabbed dry with a paper towel and cut into approximately $2 \mathrm{~cm}$ pieces with a knife.

\section{Results}

The results as depicted in Table 1 show that eleven (11) plantparasitic nematode genera were recovered from samples obtained from infected yam fields in Nasarawa State, Nigeria. The nematode genera included Pratylenchus, Hoplolaimus, Helicotylenchus, Criconema, Meloidogyne, Rotylenchus, Scutellonema, Xiphenema, Tylenchulus, Trichodorus and Rotylenchus. These plant-parasitic nematodes (PPNs) were found at different levels of incidence in yam fields surveyed. On the average, the highest incidence level of the PPNs was recorded in Lafia LGA (25.59\%) followed closely by Obi LGA (24.81\%) while the least incidence level was recorded in Awe LGA (18.14\%). Meloidogyne, Scutellonema and Pratylenchus were the only nematode genera consistently recovered from yam fields in all the LGAs assessed in the study, having incidence levels of $75.29 \%, 57.20 \%$ and $44.55 \%$, respectively. The other nematode genera occurred sparingly, in fact the survey outcome showed that Tylenchulus was only recovered from Awe LGA (7.20\%) while Trichodorus was only recovered from Lafia LGA (12.12\%) and Doma LGA (7.13\%).

Average population densities of PPNs recovered from soil were higher than those recovered from the tubers except for Meloidogyne whose population was higher in the tubers (Table 2). The total population densities when compared across locations showed that Lafia had the highest population of PPN (43 PPNs/combined composite) and closely followed by Keana (32 PPNs/combined composite) and Doma LGA (30 PPNs/combined composite). In terms of specific generic population, it was observed that Meloidogyne spp. were the most populated (91 nematodes/combined composite) closely followed by Scutellonema (88 nematodes/combined composite), Pratylenchus (37 nematodes/combined composite) and Rotylenchulus (33 nematodes/combined composite). The damage observed as a result of PPN attack on infected yams surveyed are pictorially presented in Figure 2. Damage included soft rot (Figure 2A), concomitant root-knot nematode-induced galls and soft rot (Figure 2B), necrotic lesions (Figure 2D) and abnormal proliferation of rootlets. There destructive activities result in unattractive, verrucose or knobby appearances on white yam, thereby resulting in low to extremely low tuber quality of marketable yams.

Table 1. Plant-parasitic nematode genera recovered from yam fields in six local government areas of Nasarawa state and their incidence levels.

\begin{tabular}{|c|c|c|c|c|c|c|c|}
\hline \multirow{2}{*}{ Nematode genera } & \multicolumn{6}{|c|}{ Incidence of PPN in each Local Government Area (\%) } & \multirow{2}{*}{${ }^{x}$ Incidence $(\%)$} \\
\hline & Lafia & Keana & Obi & Kokona & Doma & Awe & \\
\hline Pratylenchus & 27.24 & 33.51 & 67.24 & 43.62 & 60.17 & 35.53 & 44.55 \\
\hline Hoplolaimus & 13.40 & 11.33 & 0.00 & 0.00 & 15.21 & 11.00 & 8.49 \\
\hline Criconema & 0.00 & 0.00 & 13.50 & 0.00 & 0.00 & 0.00 & 2.25 \\
\hline Meloidogyne & 77.11 & 67.38 & 70.66 & 83.02 & 73.44 & 80.13 & 75.29 \\
\hline Rotylenchus & 0.00 & 0.00 & 0.00 & 23.50 & 0.00 & 17.11 & 6.77 \\
\hline Xiphenema & 0.00 & 0.00 & 0.00 & 0.00 & 11.11 & 0.00 & 1.85 \\
\hline Tylenchulus & 0.00 & 0.00 & 0.00 & 0.00 & 0.00 & 7.20 & 1.20 \\
\hline Trichodorus & 12.12 & 0.00 & 0.00 & 0.00 & 7.13 & 0.00 & 3.21 \\
\hline Rotylenchulus & 33.33 & 52.14 & 0.00 & 35.12 & 22.12 & 0.00 & 23.79 \\
\hline${ }^{y}$ Incidence (\%) & 25.59 & 22.06 & 24.81 & 21.84 & 21.83 & 18.14 & \\
\hline
\end{tabular}

$x=$ average incidence of nematode across LGA; $y=$ average incidence of plant-parasitic nematodes within LGA. 
Table 2. Population density of plant-parasitic nematodes recovered from $150 \mathrm{cc}$ soil rhizosphere and $10 \mathrm{~g}$ of yam in six local government areas (LGAs) of Nasarawa state, Nigeria.

\begin{tabular}{|c|c|c|c|c|c|c|c|c|c|c|c|c|}
\hline \multirow{2}{*}{ LGA } & \multicolumn{11}{|c|}{ Density of plant-parasitic nematode } & \multirow{2}{*}{ Avr. ${ }^{x}$} \\
\hline & Praty. & Hopl. & Helico. & Crico. & Meloid. & Roty. & Scutellonema & Xiphi. & Tylenchulus & Trichodorus & Rotylenchulus & \\
\hline \multicolumn{13}{|c|}{ Soil (200 g) } \\
\hline Lafia & 43 & 22 & 23 & 0 & 82 & 0 & 77 & 0 & 0 & 17 & 43 & 28 \\
\hline Keana & 51 & 17 & 8 & 0 & 48 & 0 & 79 & 0 & 0 & 0 & 37 & 22 \\
\hline Obi & 31 & 0 & 24 & 22 & 23 & 0 & 86 & 0 & 0 & 0 & 0 & 17 \\
\hline Kokona & 22 & 0 & 0 & 0 & 20 & 18 & 117 & 0 & 0 & 0 & 18 & 18 \\
\hline Doma & 33 & 18 & 0 & 0 & 20 & 0 & 103 & 42 & 0 & 20 & 33 & 24 \\
\hline Awe & 22 & 12 & 0 & 0 & 27 & 31 & 64 & 0 & 11 & 0 & 0 & 15 \\
\hline Avr. ${ }^{y}$ & 34 & 12 & 9 & 4 & 37 & 8 & 88 & 7 & 2 & 6 & 22 & \\
\hline \multicolumn{13}{|c|}{ Tuber (50 g root) } \\
\hline Lafia & 11 & 2 & 13 & 0 & 112 & 0 & 0 & 0 & 0 & 17 & 13 & 15 \\
\hline Keana & 4 & 10 & 4 & 0 & 88 & 0 & 0 & 0 & 0 & 0 & 7 & 10 \\
\hline Obi & 3 & 0 & 11 & 0 & 43 & 0 & 0 & 0 & 0 & 0 & 10 & 6 \\
\hline Kokona & 0 & 0 & 0 & 0 & 30 & 0 & 0 & 0 & 0 & 0 & 6 & 3 \\
\hline Doma & 3 & 1 & 0 & 0 & 28 & 0 & 0 & 0 & 0 & 20 & 11 & 6 \\
\hline Awe & 0 & 0 & 0 & 0 & 27 & 0 & 0 & 0 & 0 & 0 & 17 & 4 \\
\hline Avr. ${ }^{y}$ & 4 & 2 & 5 & 0 & 55 & 0 & 0 & 0 & 0 & 6 & 11 & \\
\hline \multicolumn{13}{|c|}{ Total population } \\
\hline Lafia & 54 & 24 & 36 & 0 & 194 & 0 & 77 & 0 & 0 & 34 & 56 & 43 \\
\hline Keana & 55 & 27 & 12 & 0 & 136 & 0 & 79 & 0 & 0 & 0 & 44 & 32 \\
\hline Obi & 34 & 0 & 35 & 22 & 66 & 0 & 86 & 0 & 0 & 0 & 10 & 23 \\
\hline Kokona & 22 & 0 & 0 & 0 & 50 & 18 & 117 & 0 & 0 & 0 & 24 & 21 \\
\hline Doma & 36 & 19 & 0 & 0 & 48 & 0 & 103 & 42 & 0 & 40 & 44 & 30 \\
\hline Awe & 22 & 12 & 0 & 0 & 54 & 31 & 64 & 0 & 11 & 0 & 17 & 19 \\
\hline Avr. ${ }^{y}$ & 37 & 14 & 14 & 4 & 91 & 8 & 88 & 7 & 2 & 12 & 33 & \\
\hline
\end{tabular}

Praty $=$ Pratylenchus; Hopl. $=$ Hoplolaimus; Helico. $=$ Helicotylenchus; Meloid. $=$ Meloidogyne; Roty. $=$ Rotylenchus; Xiphi. $=$ Xiphinema. Avr. $^{x}=$ Approximated average count to across rows; Avr. ${ }^{y}=$ Approximated average count across columns.
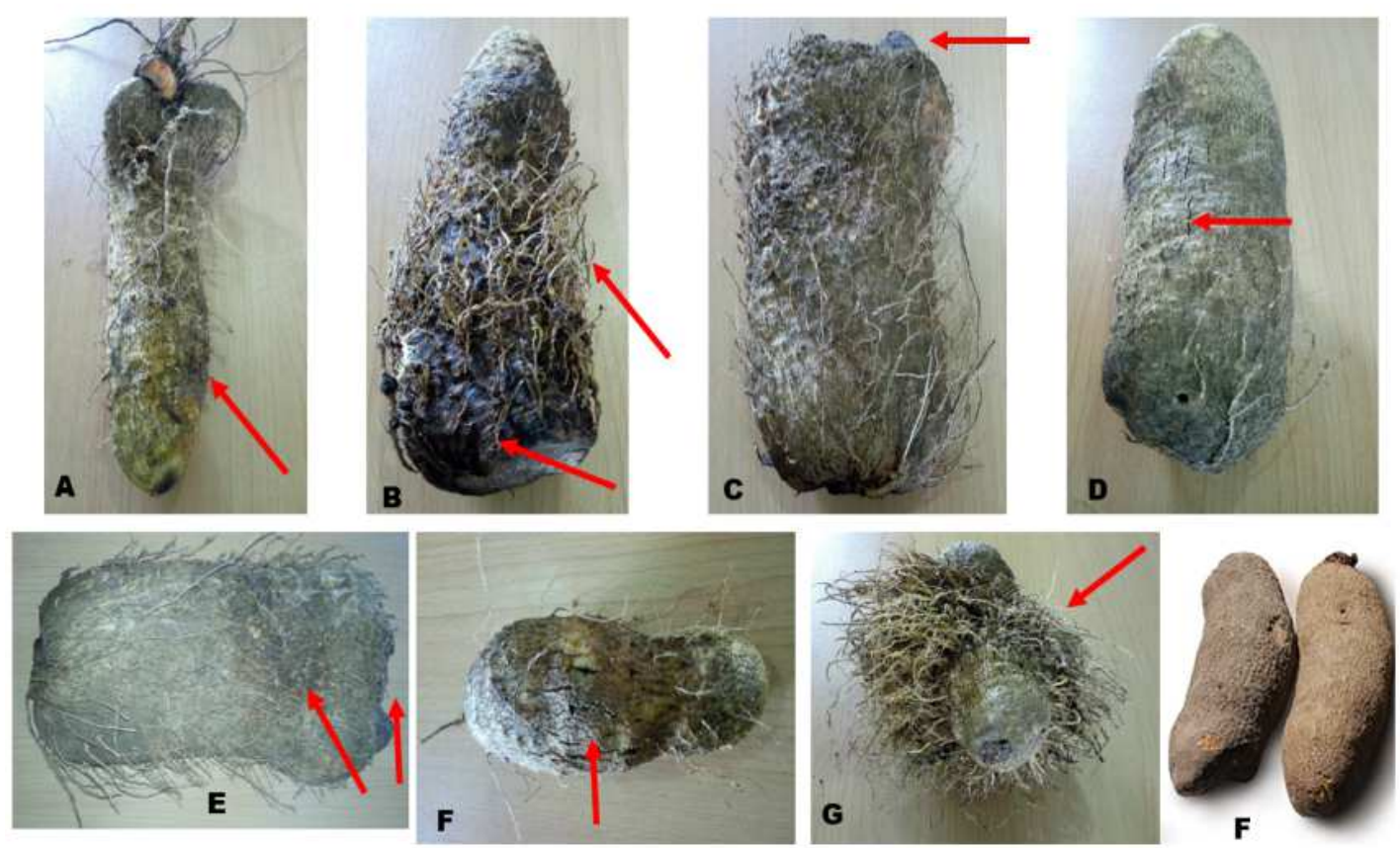

Figure 2. Some tubers of yams collected during the survey showing: (A) tuber soft rot symptom, (B) concomitant root-knot nematode induced galls and soft rot, $(C)$ soft rot, (D) necrotic lesion, $(E)$ soft rot, $(F)$ necrotic lesion, $(G)$ proliferation of rootlets and $(F)$ healthy looking yam tubers.

\section{Discussion}

Yam (Dioscorea spp.) constitute one of the most important food crops in the tropics and most important group of staple foods especially in the yam zone $\left(25^{\circ} \mathrm{N}\right.$ and $\left.25^{\circ} \mathrm{S}\right)$ of West Africa [19]. The bulk of the global Yam production is concentrated in West Africa, with Nigeria producing the largest proportion followed by Ghana and Cote d'lvoire [20]. Nasarawa State contributes immensely to the production of yams in Nigeria. However, published empirical data on incidences and associated parasitic nematode damages on yams grown from the State appeared almost nonexistent 
despite alarming reports from other yam-producing States in Nigeria. The need for baseline information or re-appraisals of the statuses and spread of plant-parasitic nematodes (PPNs) associated with yam cultivated in yam producing areas of Nigeria cannot be overemphasized. The baseline information will provide future directions which will ensure the design of specific nematode-induced disease management strategies for curbing the menace of infections in yam fields in the state. The current study has again demonstrated the abundance of plant-destructive nematode genera fields of economic crops.

Although Pratylenchus, Meloidogyne and Scutellonema were recovered from all the study locations, findings from this study showed that Meloidogyne had the highest incidence in yam fields surveyed in Nasarawa State. This finding agrees corroborates the report of Adegbite et al. [21] who found that Meloidogyne, Scutellonema and Pratylenchus in rank of descending order, were the most widely distributed plantparasitic nematodes in yam fields in Edo, Ekiti and Oyo states of Nigeria. Over time, several workers had reported that Meloidogyne, Scutellonema and Pratylenchus are highly prevalent on yam fields. Their destructive activities result in unattractive, verrucose or knobby appearances on white yam, thereby resulting in low to extremely low tuber quality of marketable yams. In an analogous study conducted in Benue State, Isegbe et al. [22] revealed that only five nematode genera were recovered from marketed yam tubers namely Scutellonema, Meloidogyne, Pratylenchus and Tylenchus. Scutellonema was reported has having the highest incidence on yam. In contrast, the current investigation, in addition to using fresh yam tubers also made use of the rhizosphere of the yam plant and was able to recover eleven plant-parasitic nematode genera with Meloidogyne having the highest incidence.

Adegbite et al. [23] reported that of the ten PPNs recovered from yam fields in Ogun and Osun States, Scutellonema was the most widely distributed while Alabi et al. [24] documented Meloidogyne as the most prevalent PPN encountered in their study. In a study carried-out by Duru et al. [25], it was reported that seven genera of PPNs were recovered with Pratylenchus as the most prevalent species, followed by Meloidogyne and then, Scutellonema. Imafidor and Mukoro [26] reported that the most encountered PPNs on yam fields, in order of descending ranking, was Pratylenchus, Scutellonema and Meloidogyne. Hinmikaiye et al. [27] reported that of the five PPNs recovered, Meloidogyne was the most prevalent plant-parasitic nematode genus in a survey conducted on yam fields in Kogi State, Nigeria. Contrastingly, the survey did not encounter Scutellonema, a nematode popularly linked to yam. Like other previous studies [28] although with divergent plethora of differential genera composition, this current study encountered, in order of descending ranking, Rotylenchulus, Helicotylenchus, Hoplaimus, Rotylenchus, Trichodorus, Criconema, Xiphinema and Tylenchulus as PPN associated with yam fields in Nasarawa State.

Although it may be argued that given the nature of variable spatial distribution of plant-parasitic nematodes communities in soils, disparity of environmental soil variables, in-situ effects of climate change, global warming and climate variability, the outcomes of surveys may synchronously be changing as well. Hence there is need for a re-appraisal of sitespecific concomitant plant-parasitic nematode communities prior to planting operations. The damages associated with the parasitic activities of these nematodes poses a serious threat to yam production in the State and calls for a concerted effort from all stakeholders in the yam value chain.

\section{Conclusion and Recommendations}

This study has documented for the first time, the extent to which yam cropping systems in Nasarawa State are affected by the deleterious activities of phyto-parasitic nematode communities. A total of eleven plant-parasitic nematode genera were recovered from surveyed yam fields in Nasarawa State. These included, in descending order of ranking, Meloidogyne, Pratylenchus, Scutellonema, Rotylenchulus, Helicotylenchus, Hoplaimus, Rotylenchus, Trichodorus, Criconema, Xiphinema and Tylenchulus. The total population densities when compared across locations showed that yam fields in Lafia had the highest population of PPN closely followed by Keana LGA. The associated damages on yam tubers obtained from the study calls for a collaborative effort among actors in the yam value chain. The Federal Ministry of Agriculture and Rural Development (FMARD) must work hand-in-hand with the Nasarawa State Ministry of Agriculture and Water Resources, and donor agencies working through non-governmental organizations (NGOS) and community-based organizations (CBOs) to increase awareness of nematode-related problems and promote veritable measures for their control to forestall quantitative and qualitative yield losses.

\section{Acknowledgements}

The author is grateful to the International Institute for Tropical Agriculture (IITA) for the research grant released to conduct the study under the project dubbed "Disease Surveillance on Yams in Benue and Nasarawa States of Nigeria". The assistance received from the Nasarawa State Agricultural Development Programme (ADP) office as well as the cooperation received from farmers who participated in study is well appreciated.

\section{References}

[1] Martin, F. W. (1976). Tropical yams and their potential, part 3, Dioscorea alata. Agriculture Handbook 495, Washington D. C., USDA Agricultural Research Services. 44 pp.

[2] Olorunsanya, E. O. (2015). A gender base economic analysis of yam production among resource poor households in Kwara State, Nigeria. Agricultura Tropica et Subtropica 48: 5-10.

[3] Showemimo, F. A. (2006). Important tuber and fibre crops of Nigeria, In; Idem, N. U. A, and Showemimo, F. A., (eds). Tuber and Fibre Crops of Nigeria: Principles of Production and Utilization, Ade Commercial Press, Zaria, Nigeria, pp. 1-10. 
[4] Phillips, D., Ogbonna, M., Etudaiye, H., Mignouna D., Siwoku, B. (2013). Nigeria: Detailed Yam Value Chain Analysis. Yam Improvement for Income and Food Security on West Africa (YIIFSWA) Pp 28.

[5] Adelusi A. A., Lawanson, A. O. (1987). Disease induced changes in carotenoid content of edible yam (Dioscorea spp) infected by Botryodiplodia theobromae and Aspergillus niger. Mycopathologia 98: 49-58.

[6] Umar A. G, Nwafor M. S., Likita S., Adoko S. (2006). The Indigenous yam storage technology and post-harvest losses in Nigeria. The Benue State perspective. International Journal of food and Agricultural Research 5 (2): 113-139.

[7] Udoh D. J., Ndaeyo N. U., Asuquo P. E., Ndon B. A. (2005). Crop production technique for the tropics. Concept's publication, Lagos, 182-187.

[8] Amusa, N. A., Adegbite, A. A, Muhammed, S., Baiyewu, R. A. (2003). Yam diseases and its management in Nigeria. African Journal of Biotechnology 2 (12): 497-502.

[9] Adjei-Nsiah, S., Asumugha, G., Njukwe, E. and Akoroda, M. (2020). The root and tuber crop farming system. p. 182-213. In: "Farming systems and food security in Africa" (Dixon J., Garrity D. P., Boffa J-M., Williams T. O., Amede T., Auricht C., Lott R., Mburathi G. eds). Routledge, NewYork, USA, 638 pp.

[10] Adesiyan, S. O., Odihirin, R. A. (1978). Plant parasite nematodes associated with yam tuber in mid-western state, Nigeria. Nigerian Journal of Plant Protection 3: 178-179.

[11] Nwauzer, E. C. and Fawole, B. (1981). Root-knot nematodes on Yams in eastern Nigeria. p. 16. In: Proceedings of the $3^{\text {rd }}$ Research planning Conference on root-knot nematodes, Meloidogyne spp. Regine IV and V. Ibadan Nigeria. Pp 1-167.

[12] Coyne, D., Cortada, L., Dalzell, J., Cole, B., Haukeland, S., Luambano, N., Talwana, H., 2018. Plant-Parasitic Nematodes and Food Security in Sub-Saharan Africa. Annual Review of Phytopathology 56 (1): 381-403.

[13] Azare, I. M., Abdullahi, M. S., Adebayo, A. A., Dantata, I. J., Duala, T. (2020). Deforestation, desert encroachment, climate change and agricultural production in the sudano-sahelian region of Nigeria. Journal of Applied Sciences and Environmental Management $24 \quad$ (1): 127-132. http://doi.org/10.4314/jasem.v24i1.18

[14] Salau, E. S. and Attah, A. J. (2012). A Socio-Economic Analysis of Urban Agriculture In Nasarawa State, Nigeria. PAT 8 (1): 17-29.

[15] Ambo, A., Aremu, M., Iyakwari, S., Etonihu, C. (2013). Geochemical studies of mineral bearing ores from Nasarawa Eggon and Udege Beki areas of Nasarawa State, Nigeria. International Journal of Basic and Applied Sciences 3: 93-108.

[16] Ricka, D. A., Barker, K. R., (1992). Nematode assays and advisory services. p 8-20. In: "Nematology in the Southern
Region of the United States" (Riggs, R. D. ed.). South Cooperative Service Bulletin 276 Arkansas Agric. Exp. Fayetteville, Arkansas.

[17] Whitehead A. G., Hemming J. R. (1965). A comparison of some quantitative methods of extracting small vermiform nematodes from soil. Annals of Applied Biology 55: 25-38.

[18] Hooper, D. J., Hallmann, J., Subbotin, S. A. (2005). Methods for extraction, processing and detection of plant and soil nematodes. Pp. 53-86. In: "Plant-parasitic nematodes in subtropical and tropical agriculture, 2nd Edition" (Luc M., Sikora R. A., Bridge J. eds). CABI Publishing. Wallingford, England, 918 pp. http://dx.doi.org/10.4314/njpar.v38i2.33

[19] Coursey, D. G., 1967. Yams. Longmans, London, UK, 230 pp.

[20] FAOStat. 2019. World Food and Agriculture-Statistical pocketbook 2019. Rome. Pp 254.

[21] Adegbite, A. A., Saka, J. O., Agbaje, G. O., Owolade, O. F., Olaifa, G. O., Lawal, A., Ojo, S. T. (2006). Survey of plantparasitic nematodes associated with yams in Edo, Ekiti and Oyo States of Nigeria. African Journal of Agricultural Research 4: 125-130.

[22] Isegbe, V., Habib, M. A., Solomon, S. (2017). Studies on the occurrence and population distribution of nematodes with yam (Dioscorea rotundata Poir) tubers in Benue State, Nigeria. Journal of Ecobiotechnology 9: 24-30. https://doi:10.25081/jebt.2017.v9.3477.

[23] Adegbite, A. A., Saka, J. O., Agbaje, G. O., Osuloye, F. O. (2008). Survey of plant-parasitic nematodes associated with yams in Ogun and Osun States of Nigeria. Journal of Plant Protection Research 48 (4): 421-428.

[24] Alabi, C. O., Atungwu, J. J., Sam-Wobo, S. O, Odeyemi, S. I. (2017). Occurrence and prevalence of nematodes in yam fields from four community-based farming scheme locations in Ogun State, Nigeria. Nigerian Journal of Parasitology 38 (2): 307-312.

[25] Duru, V., Nwankwo, C., Ogbonna, E. N., Confidence, U., Onyido, A. E., Adewuyi, O. (2015). A survey of plant-parasitic nematodes of yam farms in Awka-North local government area, Anambra state, Nigeria. Journal of Applied Biosciences 95: 8950-8957.

[26] Imafidor, H. O., Mukoro, U. L. (2016). Survey of plantparasitic nematodes associated with Dioscorea rotundata. International Journal of Agricultural Research 4: 16-19.

[27] Hinmikaiye, A. S., Abolusoro, S. A., Balogun, O. S., Nziogu, B., Abolusoro, P. F., Ogundare, S. K, Babalola, T. S, Mohammed, S. A. (2015). Survey of plant-parasitic nematodes associated with yam field in Kogi State, north central guinea savanna area of Nigeria. Researcher 7 (11): 91-95.

[28] Unny K. L., Jerath M. L. (1965). Parasitic nematodes on Dioscorea spp. in Eastern Nigeria. Plant Disease Reporter 49: 875-876. 